\title{
CULTURA E ECONOMIA: a busca de uma teoria do consumo
}

por Thais Alves Marinho*

DOUGLAS, M. O mundo dos bens, vinte anos depois. Revista Horizontes Antropológicos, Porto Alegre, v. 13, n. 28, jul./ dez. 2007.

; ISHERWOOD, B. O mundo dos bens: para uma antropologia do consumo. Rio de Janeiro: UFRJ, 2004.

Cultura e economia são categorias habitualmente identificadas com esferas distintas da atividade humana no âmbito das ciências sociais. O debate sobre tal diferenciação e aproximação se inicia, recentemente, em um contexto de globalidade, em que formas tecnológicas de vida se desenvolvem, propiciando, entre outros, um gigantesco fluxo de informações e produtos, transformações que tendem a confundir, cada vez mais, os limites entre as esferas, vislumbradas, especialmente, por práticas de consumo e discussões sobre uma teoria do consumo.

O livro O mundo dos bens, de Mary Douglas e Baron Isherwood (2004, 2007), dá um passo fundamental nessa aproximação entre cultura e economia. Propõe uma aliança entre a antropologia e a ciência econômica, acoplando estudos de economias de mercado, dos economistas e economias de dádiva, dos antropólogos, sugerindo uma definição de rede social de pobreza, na qual os bens não são necessários por eles mesmos, mas pelas relações sociais que sustentam.

* Doutoranda no Programa de Pós-Graduação em Sociologia da Universidade de Brasília (UnB). Linha de pesquisa: arte, cultura e pensamento social.E-mail: thais_marinho@ hotmail.com 
Os bens, para os autores, seriam marcadores (classificadores) sociais, constitutivos de um sistema vivo de informações, que se contemplam na interação com os indivíduos e com os outros bens; logo, na sociedade moderna, o consumo aparece como construtor de identidades e de processos de significação, pela interação. Os bens só possuem nexo dentro da interação humana, são construtores ou solventes de fronteiras, são necessários para dar visibilidade e estabilidade às categorias da cultura, já que se consome para o outro. "O consumo é um processo ativo em que todas as categorias sociais estão sendo continuamente redefinidas" (p. 112), corroborando a perspectiva de que cultura é um processo dinâmico feito por indivíduos em interação e de que o foco deve ser justamente a função comunicativa dos bens, como nos pressupostos interacionistas.

Os autores ressaltam que o indivíduo a ser considerado como consumidor não deve ser o que busca consumir apenas para sua satisfação física, para seu uso privado ou familiar; ele não escolhe meramente objetos e coisas, como na teoria da dádiva. Segundo Douglas $(2007)^{1}$,

[...] o consumidor é inerentemente um animal social, o consumidor não quer objetos para ele mesmo, mas para dividir, dar, e não só dentro da família. O maquinário da teorização e medição econômica foi criado para a idéia de que o consumo é uma atividade de indivíduos. A teoria está presa nessa noção. [...] A teoria deveria começar com seres inteligentes que têm o suficiente para viver e mesmo assim conseguem matar a fome de alguns de seus iguais. Pobreza é uma questão de como as pessoas tratam umas às outras, e isso precisa de um enquadramento sociológico.

Dessa forma, o indivíduo deve ser encarado como ser comunicativo, dependente de outros, que calculam, negociam,

1 Artigo publicado na Revista Horizontes Antropológicos em 2007, fruto de uma conferência em Birbeck, em 1999, para o Warwick Luxury Project, intitulado O mundo dos bens, vinte anos depois. 
escolhem, maximizam diante de uma rede de interações e significados e que, portanto, possuem algum poder comunicativo inerente, como os bens. As pessoas que consomem compartilham um universo de nomes e classificações, um conhecimento, um saber sobre produtos e serviços, em que o saber é apreendido e classificado culturalmente, pelo consumo. A antropologia tem como foco principal do consumo esse compartilhamento de saberes, de nomes.

Essa visão foi antes negligenciada pelos economistas, que iniciam a análise pelo aspecto meramente físico do consumo, enfatizando necessidade física e básica em detrimento de necessidades sociais: os bens seriam, primordialmente, necessários à subsistência e à exibição competitiva. A esfera do econômico, geralmente, é identificada com a idéia de necessidade, com a qual participa no quadro de diversas outras associações simbólicas que são importantes para a compreensão de sua evolução. Entre elas, encontram-se as que aproximam o econômico de idéias ou categorias, também historicamente mutáveis, como as de subsistência e escassez, de natureza e animalidade, de produção, trabalho e consumo, de material e vulgar, de riqueza e dinheiro, de racionalidade e egoísmo, enquanto que a esfera da cultura é claramente identificada com a lógica da liberdade, em que a principal necessidade suprida pelo consumo é a simbólica.

A intenção dos autores, ao fazer essas ponderações, não é adotar um discurso normativo, mas apontar a urgência de um projeto que estabeleça uma base teórica para estudar o consumo, que leve em consideração a importância da ótica antropológica e cultural, em contraste com os argumentos economicistas predominantes. Para tanto, criticam a economia neoclássica, que lança mão de abordagens utilitaristas, naturalistas, hedonistas do consumo, bem como as teorias de emulação estabelecidas a partir de Veblen.

Os autores atentam para a arduidade de tal projeto, que não pretende se esgotar nessa obra, mas, sim, servir de estímulo ao propor 
uma nova abordagem epistemológica sobre o consumo e fomentar o debate em torno desse objeto, sugerindo uma perspectiva diferente para a política social.

Como sistema de informação, os bens dizem respeito, também, às relações de poder. Os autores rejeitam a idéia de que o consumidor, como indivíduo, deva ser considerado manipulável, seja pela publicidade, seja pela mídia. Essa perspectiva se ampara na crença dos economistas em uma teoria que seja moralmente neutra e vazia de julgamento e na busca da mesma, o que os alija da responsabilidade da crítica social (p. 141-142). Na perspectiva dos autores, o poder é mantido e exercido de maneiras múltiplas e diferenciadas. A abordagem antropológica, nesse sentido, é fundamental, já que captura todo o espaço de significação em que os objetos são usados depois de comprados, pois toma a realidade social como dada e socialmente construída, sem desvincular cultura de organização, embora marginalize a estrutura social.

Como parte de nexos de poder (informação), as esferas do consumo são distintas, hierarquizadas e fornecem uma base para se discernir entre bens. Assim, fala-se em bens de luxo, bens necessários ou básicos, entre outros. Os bens de luxo, em uma sociedade diversificada, também possuem demandas diversificadas e, paradoxalmente, existe uma tendência à padronização, ao mesmo tempo em que distinguem, padronizam, mediante competição e controle social acirrado ou forte. Nessa perspectiva, pequenas diferenças fariam grande diferença. Assim, produção e consumo fazem parte de um sistema circular, no qual a divisão dos bens é a expressão da divisão social e resulta em diferenças nas escalas de consumo. Os bens reais seriam "a ponta visível do iceberg" e o que está submerso é um universo informacional, de classificações de nomes, lugares, pessoas, objetos, datas, etc.

Os autores seguem afirmando existir uma competição para adquirir bens na classe de informação, o que gera barreiras 
para admissão e técnicas de exclusão no grupo, visto que, independentemente da (in)justiça da distribuição de produção e oportunidades educacionais, os consumidores tendem a criar círculos internos exclusivos e a controlar o acesso a certos tipos de informação. Os grandes consumidores de informação são também os grandes produtores de bens de informação e todo o público usa o setor de informação.

A pobreza seria definida, então, pelo tipo de relacionamento do indivíduo com a informação. É nessa perspectiva que os bens marcam a pobreza, não pela quantidade em que são consumidos ou não consumidos, mas pela reciprocidade, pelo consumo de bens semelhantes trocados dentro de cada esfera, gerando um arcabouço de conhecimento e não se relacionando com outros de outra esfera, pela exclusão da rede de saberes constituída pela troca desses bens. Entretanto, dispor do bem em si não constitui a única possibilidade de consumo: esta pode ser realizada pelo consumo da informação sobre o produto, informação esta potencialmente admitida nos rituais das esferas mais ricas. Mesmo alijado do bem materialmente constituído, o indivíduo pode ser socialmente aceito, pois há um saber em comum a ser compartilhado, ainda que subjetivamente.

Essa admissão na classe mais elevada seria fundamental, já que possibilitaria o acesso à informação e o domínio da mesma e da competência de julgamento dos bens e serviços de informação, que podem vir a ser uma qualificação para o emprego nesse setor mais bem pago. Assim, ingressar no setor de serviços do sistema produtivo é mais fácil pela entrada prévia na classe social que consome o conjunto dos bens de informação. O consumo, agora, aparece associado com ganhos da economia como um todo.

Os autores finalizam o livro chamando a atenção para a importância da periodicidade no consumo e a sincronização das responsabilidades. Ressaltam a multidisciplinaridade de tal objeto, 
evocando para o debate os sociólogos que poderiam contribuir na construção da ponte que une as esferas da cultura e da economia, ultrapassando a visão materialista que os economistas têm do consumo e fortalecendo a posição dos antropólogos de que a teoria do consumo é parte do problema da pobreza, complementando a explicação que é limitada ao resultado do sistema de produção, usualmente posto. 